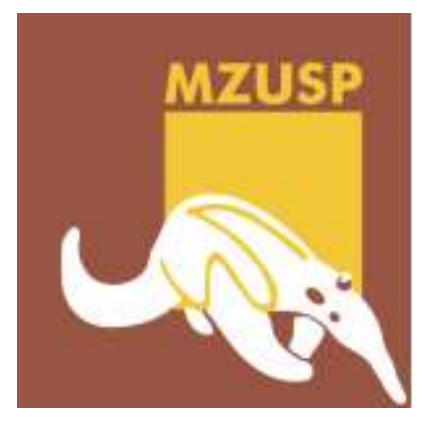

\title{
Museu de Zoologia
} Universidade de São Paulo

Georgette Paola Ancajima Alcalde

Comparative morphology of the epiphyses of Dilophonotini Burmeister, 1878 and Philampelini Burmeister, 1878 (Lepidoptera: Sphingidae)

Morfologia comparada das epífises de Dilophonotini Burmeister, 1878 e Philampelini Burmeister, 1878 (Lepidoptera: Sphingidae) 


\title{
Comparative morphology of the epiphyses of Dilophonotini Burmeister, 1878 and Philampelini Burmeister, 1878 (Lepidoptera: Sphingidae)
}

\author{
Morfologia comparada das epífises de Dilophonotini \\ Burmeister, 1878 e Philampelini Burmeister, 1878 \\ (Lepidoptera: Sphingidae)
}

Corrected Version

Thesis submitted to the Graduate Program of the Museu de Zoologia da Universidade de São Paulo in partial fulfillment of the requirements for the degree of Master of Science (Systematics, Animal Taxonomy and Biodiversity).

Advisor: Prof. Dr. Marcelo Duarte da Silva. 
I authorize the reproduction and dissemination of this work in part or entirely by any electronic or conventional means, for study and research, provide the source is cited.

\section{Serviço de Biblioteca e Documentação}

\section{Museu de Zoologia da Universidade de São Paulo}

\section{Cataloging in Publication}

Alcalde, Georgette Paola Ancajima

Comparative morphology of the epiphyses of Dilophonotini Burmeister, 1878 and Philampelini Burmeister, 1878 (Lepidoptera: Sphingidae) = Morfologia comparada das epífises de Dilophonotini Burmeister, 1878 and Philampelini Burmeister, 1878 (Lepidoptera: Sphingidae) / Georgette Paola Ancajima Alcalde; orientador Marcelo Duarte da Silva. São Paulo, 2021.

$259 p$.

Monografia - Programa de Pós-Graduação em Sistemática, Taxonomia e Biodiversidade, Museu de Zoologia, Universidade de São Paulo, 2020.

Versão corrigida

1. Sphingidae - Epífises. 2. Dilophonotini. 3. Lepidoptera - Sphingidae. I. Silva, Marcelo Duarte da orient. II. Título. 


\section{ABSTRACT}

Hawkmoths occupy all regions of the globe, except Antarctica and Greenland. The family has 210 genera and about 1500 species, with about a third of the taxa registered for the Neotropical region. In Brazil, 33 genera and 196 species are known. They are classified into three subfamilies, with Macroglossinae being the most diverse lineage. They play an key in pollination. In this process, sphingids usually have contact with pollen grains in various parts of the body, particularly in the antennae. To clean them, these moths use the epiphyses that are in the foretibiae. In addition to being important for the biology of lepidopterans, the epiphysis also represents one of the synapomorphies that support the monophyly of these insects. However, few studies detail this structure morphologically. In this study, we seek to understand the possible variations in the epiphyses of representatives of Dilophonotini and Philampelini aiming to contribute to the discussions on the structure morphology, sexual dimorphism and the relationship with other body structures. For this, 19 genera and 59 species of both sexes (564 individuals in total) were studied. The extracted legs were placed in $10 \% \mathrm{KOH}$ and taken to a water bath for four minutes to remove the scales. With the epiphyses cleaned, all individuals were photographed using a stereomicroscope and SEM to perform morphological descriptions of the epiphyses and measurements; after that, an allometric regression analysis was performed with other body structures (length and width of the epiphyses, position, length of the tibiae and length of the antennae); finally, an analysis of geometric morphometrics was conducted. As results, a new terminology was proposed for distinct parts of the epiphysis, 22 morphological characters were established from the epiphyses, greater morphological variation was found in the genera and subtribe levels, variations were found between males and females, a positive allometry was observed between the size of the epiphyses and the size of the antennae, and likewise, between the position of the epiphyses and the length of the tibiae. Morphometric analysis showed positive allometry, a homogeneous pattern with small variations between some genera. It was demonstrated that closely related genera have similar epiphyses, and others do not. This study is an important contribution to the knowledge of the Sphingidae morphology, with the proposal of new phenotypic 
characters for the group. In addition to being a detailed study of the epiphysis, a structure that has been historically neglected, it highlights the need to expand the comparative analysis to other groups of Lepidoptera for a better understanding of the importance of using the epiphysis morphology in the taxonomy of these insects, as well as for a better understanding of the variation and evolution of the structure and its associated antennal grooming behavior.

Keywords: "hawkmoths". "grooming structure". "allometry". "sexual dimorphism". "geometric morphometrics". 


\section{RESUMO}

Esfingídeos habitam todas as regiões do globo, exceto Antártida e Groenlândia. A família possui 210 gêneros e cerca de 1500 espécies, com cerca de um terço dos táxons registrados para a região neotropical. No Brasil, são conhecidos 33 gêneros e 196 espécies. Os esfingídeos estão classificados em três subfamílias, sendo Macroglossinae a linhagem de maior diversidade. Desempenham um papel importante na polinização. Nesse processo, costumam ter contato com os grãos de pólen em várias partes do corpo, particularmente nas antenas. Para limpá-las utilizam as epífises que estão localizadas nas tíbias anteriores. Além de ser importante para a biologia dos lepidópteros, a epífise também representa uma das sinapomorfias que sustentam a monofilia desses insetos. Porém, existem poucos estudos que detalham morfologicamente esta estrutura. Neste estudo, procura-se compreender as possíveis variações das epífises de representantes de Dilophonotini e Philampelini com o objetivo de contribuir para as discussões sobre a morfologia da estrutura, dimorfismo sexual e a relação com outras estruturas do corpo. Para isso, foram estudados 19 gêneros e 59 espécies, de ambos os sexos (564 indivíduos em total). As pernas extraídas foram colocadas em $\mathrm{KOH}$ a $10 \%$ e levadas a banho-maria durante quatro minutos para remoção das escamas. Com as epífises limpas, todos os indivíduos foram fotografados com auxílio de estereomicroscópio e MEV dando subsídios às descrições morfológicas das epífises e medições; na sequência, foi realizada uma análise de regressão alométrica com outras estruturas do corpo (comprimento e largura das epífises, posição, comprimento das tíbias e comprimento das antenas); finalmente, foi conduzida uma análise de morfometria geométrica. Como resultados, foi proposta uma nova terminologia para diferentes partes da epífise, foram estabelecidos 22 caracteres morfológicos nas epífises, foi encontrada maior variação morfológica nos níveis de gênero e subtribo, foram encontradas variações entre machos e fêmeas, foi observada uma alometria positiva significativa entre o tamanho das epífises e o tamanho das antenas, e do mesmo modo, entre a posição das epífises e o comprimento das tíbias. A análise morfométrica mostrou corroborou uma alometria positiva, um padrão homogêneo com pequenas variações entre alguns gêneros; foi ainda demostrado que gêneros proximamente relacionados podem ter epífises parecidas ou 
pouca semelhança nas epífises. Esse estudo é uma contribuição importante para o conhecimento da morfologia dos Sphingidae, com a proposição de novos caracteres fenotípicos para o grupo. Além de ser um estudo detalhado da epífise, uma estrutura historicamente negligenciada, ressalta-se a necessidade de se ampliar a análise morfológica comparativa para outros grupos de Lepidoptera, no intuito de embasar o uso da descrição da epífise na taxonomia desses insetos, como também para melhor compreensão sobre a variação e a evolução da estrutura e do comportamento de limpeza das antenas.

Palavras-chave: "esfingídeos". "órgão de limpeza". "alometria". "dimorfismo sexual". "morfometria geométrica". 


\section{INTRODUCTION}

\subsection{Sphingidae Latreille, $\mathbf{1 8 0 2}$}

Lepidoptera comprises butterflies and moths with approximately 160,000 described species (Van Nieukerken et al., 2011). Moths with nocturnal habits represent $>75-85 \%$ of lepidopterans species diversity (Kawahara et al., 2018). Bombycoidea is one of the most diversified and species-rich lineages of the clade Macroheterocera (Mitter et al., 2017; Kitching et al., 2018). This superfamily includes 10 families, among them, we highlight Sphingidae Latreille, 1802 for its species richness, relatively stable taxonomy, and its importance in studies of pollination and biological conservation (Kristensen, 1999; Van Nieukerken et al., 2011; Kitching et al., 2018).

Sphingidae comprises 210 genera and more than 1500 species (Van Nieukerken et al., 2011; Kawahara and Barber, 2015; Kitching et al., 2018); therefore, it constitutes the most species-rich group of Bombycoidea (Van Nieukerken et al., 2011). Hawkmoths have a worldwide distribution, and are absent only in Antarctica and Greenland (Kitching and Cadiou, 2000; Moré et al., 2014). In the Neotropical region, they represent approximately one third of the global diversity (Heppner, 1991; 1998). In Brazil, 33 genera and 196 species are known (Haxaire and Mielke, 2020).

The monophyly of Sphingidae is supported by synapomorphies of larvae (1), pupae (1) and adult (7) (Minet, 1994). Currently, it is also corroborated by molecular and morphological data (Kawahara et al., 2009). Several authors classify Sphingidae in three subfamilies: Macroglossinae, Sphinginae and Smerinthinae (Kitching and Cadiou, 2000).

Initially, few researchers explored morphological data in the construction of a relationship hypothesis for Sphingidae. Rothschild and Jordan (1903) showed a comparative morphological study based on adults, however lacking a methodological standardization. These authors divided the family into two groups: "Semanophorae" and "Asemanophorae" by the presence or absence of microtrichia patch on the internal surface of the first segment of the labial palps. 
Hodges (1971) changed the names of the groups recognized by Rothschild and Jordan (op.cit.) to Macroglossinae and Sphinginae, respectively, based on the genus type of each subfamily. On the other hand, Minet (1994) indicated that the absence of the modification in the labial palp was plesiomorphic, therefore, it could not be used as an autapomorphy of Sphingidae sensu Rothschild and Jordan (1903). However, Kitching and Cadiou (2000) indicated that among the three proposed subfamilies (Sphinginae, Smerinthinae and Macroglossinae), only Macroglossinae showed an exclusive apomorphy (modification of the labial palp).

Of all the implications for the classification of Sphingidae, Nakamura (1976) (apud Kawahara et al., 2009) made the major contribution to the systematics of the family, grouping Smerinthini and Sphingini in a clade based on larval and pupal characters, but it is important to emphasize that only Japanese representatives were examined. Posteriorly, Regier et al. (2001) worked on the first molecular phylogeny for the hawkmoths. They employed only two genes (EF-1 $\alpha$ and DDC) and low representation of taxa (18 genera; 14 of Sphingidae, two of Brahmaeidae and two of Saturniidae); despite that, their results corroborated those proposed by Rothschild and Jordan (1903) and Nakamura (1976). However, it was evident that the number of genera might be expanded and three important tribes that were not previously considered (Acherontiini, Ambulycini and Sphingulini) in those works might be added in future analyses.

The study of Kawahara et al. (2009) supported what was found by previous authors, grouping Smerinthinae plus Sphinginae, and confirmed Macroglossinae as a monophyletic group. In the latter, three groups are recognized: Hemarina, Dilophonotina sensu lato and Macroglossini sensu stricto (Kawahara et al. 2009). The "Dilophonotina sensu lato" groups exclusively representatives from the Neotropical region and includes Dilophonotini (except Hemarina), Philampelini and Proserpinus group with Amphion and Sphecodina (Kitching and Cadiou, 2000; Kawahara et al., 2009). Implications from this phylogeny include the closest relationship of Hemarina and Dilophonotini, and the inclusion of the genus Enyo in the tribe Dilophonotini. 
Kawahara and Barber (2015) analyzed the evolution of anti-bat ultrasound in Sphingidae based on molecular and behavioral data and concluded that: 1) the subtribe Hemarina is phylogenetically close related to Macroglossini, 2) Enyo is placed in Macroglossina and 3) Philampelini comprise only one genus, Eumorpha. On the other hand, the global checklist of Bombycoidea proposed by Kitching et al. (2018) concluded that: 1) Hemarina is considered as tribe, 2) Philampelini is considered as subtribe of Dilophonotini including 11 genera (e.g. Aleuron, Enyo, Unzela and Eumorpha).

There are several conjectures about the Macroglossinae taxonomy. I decided to work with the classification of Kawahara et al. (2009), using the clade Dilophonotini sensu lato on which it is included the subtribe Hemarina (Cephonodes and Hemaris) without Proserpinus group.

\subsection{Grooming in insects}

Grooming is a normal and innate behavior in animals (Jander, 1966; Murray, 1987; Böröczky et al., 2013). This behavior is performed frequently to avoid contamination on the body surface (Hlavac, 1975; Böröczky et al. 2013; Zhukovskaya et al. 2013). Thus, it helps maintaining the acuity of the sensory organs (Robinson, 1996; Böröczky et al., 2013; Hackmann et al., 2015), removing pathogens, fungi (Chouvenc et al. 2009; Yanagawa et al. 2014), dirt and pollen from the body (Jones and Jones, 2001; Hackmann et al., 2015). Also, grooming prevents attacks by ectoparasites (Pettis and Pankiw, 1998; Léonard et al., 1999; Leung et al., 2001) and parasitoids (Vincent and Bertram, 2010). Additionally, parasitoids clean the antennae to remove compounds released by the hosts, without which it could compromise the location of new host and their own fitness (Corbet, 1973).

Another advantage of the grooming behavior is to help in locomotion (Wendler and Vlatten, 1993). Finally, grooming helps the distribution of hydrocarbons, brochosomes, antiseptic, antimicrobial and grooming secretions over the body surface (Kovac and Maschwitz, 1990, 1991; Lusebrink et al., 2008; Böröczky et al., 2013; Dong and Huang, 2013). 
Grooming is, as seen, a crucial and beneficial behavior for the development of insects. The insects are numerous, a diverse group (Grimaldi and Engel, 2005; Trautwein et al., 2012; Misof et al., 2014), and they developed distinct types of adaptation for cleaning (Jander, 1966; Hlavac, 1971, 1975; Robbins, 1989; Hackmann et al., 2015).

Based on the phylogenetic hypothesis of the insect evolution of Trautwein et al. (2012) and Misof et al. (2014), the antennal grooming in these animals is described in the following paragraphs.

Archaeognatha cleans the body with oral grooming; there are no reports about antennal grooming, instead they used only the mouthpiece (Valentine 1986, Basibuyuk and Quicke 1999), while Thermobia domestica (Packard, 1873) (Zygentoma) uses the first pair of legs and the oral apparatus (Jander, 1966; Valentine, 1986).

In Palaeoptera, the dragonflies (Odonata) clean head, antennae, and eyes using only their legs and post-tarsus (Jander, 1966; Leung, et al., 2001). Jander (1966) tried to document the cleaning behavior in mayflies (Ephemeroptera) without success. She concluded that they possibly missed this behavior or it is unknown yet (Jander, 1966; Jander and Jander, 2011).

There are several studies of grooming in Polyneoptera. Many species of grasshoppers (Orthoptera) hold the antennae with the prothoracic legs and pull into the mouth to clean them (Jander, 1966; Lefebvre, 1981; Chapman, 1998). As opposed, Diradius vandykei (Ross, 1944) (Embioptera) does not use the legs to assist in cleaning, instead, it uses the basal musculature of the antennae. With this musculature, the antennae are bent and held by the mouthparts, and the flagellomeres are gradually cleaned (Jander, 1966; Valentine, 1986).

Grylloblattodea also uses the front legs to bend the antennae towards the mouth to clean them as observed in Orthoptera (Kostromytska et al., 2015). In Aborolabis mauritanica (H.Lucas, 1849) (Dermaptera) the antennae reach to the mouthpiece by a sudden movement, and there, they are cleaned piece by piece (Jander, 1966). We can also observe Dermaptera using the legs to place the antennae on the mouthparts (Valentine, 1986), thus, the grooming can be of two types in Dermaptera. Zorotypus 
hubbardi Caudell, 1918 (Zoraptera) pulls the antennae with the prothoracic legs towards the mouthpiece, and remain there to hold the antennae, while they are cleaned by the mouthparts (Valentine, 1986), however, as mentioned by this author it may not be a standard behavior for the species, concluding that sampling was biased.

Within the Dictyoptera (Trautwein et al., 2012), the praying mantises (Mantodea) use the first pair of legs to move the antennae to mouth, thus cleaning the flagellomeres with the mouthparts (Jander, 1966; Valentine, 1986; Basibuyuk and Quicke, 1999). Similarly, Blattodea also clean the antennae with the mouthparts (Robinson, 1996; Chapman, 1998). Battela germanica Linnaeus, 1767 uses the labium and maxilla for the antennal grooming (Robinson, 1996); however, some cockroaches clean the antennae with the mandibles (Chapman, 1998). This behavior in cockroaches may vary among families (Smith and Valentine, 1985). There are few studies with termites (Isoptera) on cleaning behavior; however, the grooming is like other Dictyoptera, they also employ the first pair of legs to place the antennae on the mouthparts and there the grooming is performed (Grassé, 1986). In summary, several studies within Polyneoptera show that these insects use the forelegs to bring the antennae to the mouthparts, except in Diradius vandykei (Ross, 1944) (Embioptera), which uses the basal muscles of the antennae.

Paraneoptera includes Psocoptera, Phthiraptera, Thysanoptera and Hemiptera. They all possess piercing-sucking mouthparts (Grimaldi and Engel, 2005; Trautwein et al., 2012; Misof et al., 2014), therefore they do not employ the mouthparts for the antennal grooming (Jander, 1966; Hlavac, 1975). Jander (1966) indicated that Ectopsocus parvulus Kolbe, 1880 (Psocoptera) might perform a derivative behavior using the prothoracic legs. Regarding the order Phthiraptera, no information about grooming is available. On the other hand, there are reports about wing cleaning in thrips (Thysanoptera) (Ellington, 1980; Mound and Walker, 1982; Moritz, 1999), but, again, no data on the antennal grooming was found in the literature.

Hemiptera is the most diverse order of hemimetabolous insects (Grimaldi and Engel, 2005). Heteropterans use a comb located at the apex of the foretibia to clean the 
antennae, and it has been observed in Nezara viridula Linnaeus, 1758 (Pentatomidae), Oncopeltus fasciatus (Dallas, 1852 ) (Lygaeidae) and others species (Hlavac, 1975; Barão et al., 2013; Rebora et al., 2019). Other structures may also be found on the tibia of Asopinae (Pentatomidae). Foretibial expansion with a channel on the ventral surface and the foretibial apparatus have been reported, but the function of both structures is unknown (Brugnera et al., 2018). In summary, paraneopterans do not use the mouthparts for antennal grooming, which is done by the first pair of legs.

Holometabola or Endopterygota is a well resolved phylogenetically group and the most diverse lineage of living being on the planet (Grimaldi and Engel, 2005; Trautwein et al., 2012; Misof, et al., 2014). There is wide grooming diversity in this group.

Many hymenopterans employ a specialized tibia-tarsal complex (named as strigilis by some authors, Schönitzer and Lawitzky, 1987) on the prothoracic legs for cleaning the antennae. The tibia-tarsal complex is composed of a notched (on the inner surface of the proximal end of the basitarsus) and a movable tibial spur (Thelen and Farish, 1977). Several authors have studied the behavior and the structure involved in the grooming (Schönitzer and Renner, 1984; Schönitzer and Lawitzky, 1987; Hackmann et al., 2015). Bees (Apidae) have a tibial-tarsal complex with comb in the notched (Schönitzer and Renner, 1984). Ants (Formicidae) have a spur (called strigilis) with comb and bristles, and a notched with comb, bristles and brush (Schönitzer and Lawitzky, 1987; Hackmann et al., 2015). Mutilids (Mutillidae) have a velum with a smooth edge and two rows of teeth in the apex, a notched deeper than ants; tiphiid wasps (Thiphiidae) show diversity in the antenna cleaner (Schönitzer and Lawitzky, 1987) and paper wasps (Vespidae) do not have a specialized tibia-tarsal complex for the antenna grooming (Sumana and Starks, 2004).

Hymenopterans pass the entire length of the antenna through antenna cleaner using one or two legs (Farish, 1972; Basibuyuk and Quicke, 1999). Finally, they clean the tibia-tarsus complex with the mouthparts (Jander, 1966) or rubs the prothoracic legs along the antenna (Vespidae) (Sumana and Starks, 2004). A more detailed review about the grooming in hymenopterans may be consulted in Farish (1972). 
Strepsiptera has no information about the antenna grooming, even its biology is complex (Kathirithamby, 1989; Cook, 2014). Coleoptera that is the sister group of Strepsiptera is one of the most diverse groups in Holometabola (Trautwein et al., 2012). Beetles have two types of grooming, one of them includes the forelegs, and in the other there is, an antenna cleaner (specialized structure for grooming) (Jander, 1966; Hlavac, 1971; Valentine, 1973). The grooming employing the forelegs can be "antenna-clean" or "antenna rub". The antenna-clean mechanism is when the foretibia or tarsus reaches the antenna and pulls it into mouth where it is cleaned with a chewing motion. It has been observed in 27 families of Coleoptera except in most weevils, Carabidae, Cicindelidae, and some Cerambycidae and Meloidae (Valentine, 1973). Antenna rub is when the foretibia or tarsus rub along of the antenna, starting at or near the base and progressing distally. After cleaning the antennae with the foretibia, these beetles clean the legs using the mouthparts, and this behavior has been recorded in 29 families, but it is absent in non-anthribid weevils and Cicindelidae (Jander, 1966; Valentine, 1973).

The antenna cleaners or grooming tools have been described in Carabidae and Chrysomelidae. These can be formed from setal aggregations on the foretibia (Carabidae), or can be comb-like array of cuticle outgrowths (Chrysomelidae) (Hlavac, 1971; Hosoda and Gorb, 2011). On the other hand, the loss of oral antennal cleaning in Adephaga indicates that this type of behavior can have independently evolved within the order (Valentine, 1986).

The grooming behavior is similar among the three orders in the clade Neuropterida. Neuropterans hold the antennae between both forelegs (Jander, 1966; Chapman, 1998). Jander's investigation describes antenna grooming in representatives of Chrysopidae, Hemerobiidae, Osmylidae and Myrmeleontidae. Chrysopidae, Hemerobiidae and Osmylidae rub the head with both tarsi of the forelegs, thus hold the antenna from the base with the crossed tarsi and they form a big loop that is cleaned from the base to the tip. Antlions (Myrmeleontidae) have short antennae therefore and may not loop them as in the other families mentioned previously. On the other hand, dustywings (Coniopterygidae) have a similar behavior but they bow their heads to the 
side and cross both forelegs at the level of their tibiae and pull the antenna down towards the front. Finally, Libelloides coccajus (Denis \& Schiffermüller, 1775) (Ascalaphidae) grooms the antennae using only one leg and the cleaning movements are slow compared to Chrysopidae.

The behavior cleaning in Megaloptera was observed in Sialis fuliginosa Pictet, 1836 (Jander, 1966). These insects employ the forelegs for antenna grooming. First, the head and thorax are moved down; after that, both antennae are cleaned together with the forelegs. In the same way, the grooming in Raphidioptera was described in Jander (1966). The species Raphidia notata Fabricius, 1781 and Agulla sp. clean the antennae using the forelegs. Both forelegs are held together and pass through both antennae, remarkably similar to the behavior of the megalopterans (Acker, 1966; Jander, 1966).

Amphiesmenoptera is well-established as a monophyletic group and includes Trichoptera and Lepidoptera (Kristensen et al., 2007; Mitter et al., 2017). Trichoptera has a report about cleaning behavior. Phryganea striata Linnaeus, 1758 and Limnephilus flavicornis (Fabricius, 1787) put both antennae horizontally forward in parallel and with both tarsi (forelegs) take both antennae to clean them (Jander, 1966).

Butterflies and moths (Lepidoptera) have two kinds of antennal grooming behavior: with or without a specialized grooming structure (Philpott, 1924; Jander, 1966; Robbins, 1989). In many lepidopterans, antenna cleaning is done with the epiphysis, a structure located in the foretibia (details below in section 1.3) (Philpott, 1924; Jander, 1966; Odell et al., 1982; Robbins, 1989). However, other groups lack the epiphysis; they use other mechanisms for grooming. In Pieridae, grooming occurs with the movement of the foretibia and tarsus against the antennae. They may or may not possess a brush of long scales on the foretibia and a scale brush on the middle tibia (Robbins, 1989). The families Lycaenidae, Riodinidae and Nymphalidae do not have a brush on the foretibia or on the middle tibia. These butterflies clean the antennae by moving them between the basal middle tibia and distal midleg femur; or midleg tarsus and middle tibia (Jander, 1966; Robbins, 1989). 
Mecoptera and Siphonaptera are sister groups closest relatives of Diptera in the clade Antliphora (Misof et al., 2014). There are few records of the grooming behavior in Mecoptera (Setty, 1940; Jander, 1966). One of them described the antennal grooming of these insects (Jander, 1966). The genus Panorpa cleans the antennae with both forelegs; they grip the antenna from the base, and forming a concavity between the protarsus and the spurs of the foretibia through which the antenna passes to be cleaned (Jander, 1966), and the other author does not mention antennal grooming (Setty, 1940). For Siphonaptera, no information about grooming was found in the literature.

Diptera has few information about antennal grooming. There is one report of antennal grooming in Brachycera; Musca domestica Linnaeus, 1758 (Muscidae) does not use the mouthparts for antennal grooming, but instead it sweeps the forelegs for cleaning head appendages (Barber and Starnes, 1949). This behavior is similar to the specie Volucella inflata (Fabricius, 1794) (Syrphidae), this species usually rubs one antenna between the raised forelegs (Jander, 1966).

In contrast, mosquitoes (Culicidae) and biting midges (Ceratopogonidae) have a structure for grooming (Linley and Cheng, 1974; Walker and Archer, 1988). The females of Ochlerotatus triseriatus (Say, 1823) (Culicidae) bear tibial combs that function as grooming organs. They grasp the antenna with apices of both foretibia with both legs working synchronously (Walker and Archer, 1988), and Culicoides melleus (Coquillett, 1901) and C. furens (Poey, 1853) (Ceratopogonidae) have comb with spines on the fore and hind legs, and the grooming organs are sexually dimorphic. There is a similarity between the antennal grooming of Diptera (Muscidae and Syrphidae) and Mecoptera due to use of the forelegs (Barber and Starnes, 1949; Jander, 1966).

To briefly summarize, the wingless insects have an oral grooming with (Zygentoma) or without use of the legs (Archaeognatha). In Palaeoptera, oral grooming is lacking, and in Polyneoptera, except for Embioptera, it is regained. In Paraneoptera, the oral grooming is not observed due to the type of mouthpart, but in Hemiptera it is present as a structure for antennal grooming. Then, until Paraneoptera (except for Hemiptera), there was no specialized structure for the cleaning function. On the other 
hand, certain holometabolous have a complex antenna cleaning, showing some exclusive and specialized structures for this purpose. Thereby, Hymenoptera, Coleoptera, Lepidoptera and Diptera have these grooming structures, which coincidentally are the most diverse groups of Insecta.

\subsection{Epiphysis: Origin of term, description of structure, function, shape and importance}

A historical review of term 'epiphysis' is provided in the present study, based on all bibliographic sources at our disposal. At the beginning of the 19th century, Fabricius (1807) published a glossary of entomological terms. The term Pedes is referred for the legs of the Lepidoptera, but in the description, there is no single allusion to the epiphysis.

Kirby and Spence (1826) mention that in the foretibia of Lepidoptera and Trichoptera possess two or three mobile spurs called 'Calcaria', which are positioned at the apex or in the middle tibia. This term would be what is known as 'epiphysis' today. Burmeister and Shuckard (1836) also described spurs using the term 'Calcaria', but these authors did not mention its presence in Lepidoptera. Thus, the descriptions of species were made without considering the epiphysis as a taxonomic character (Walker, 1869). A year later, Meyrick $(1895$, p. 4) mentioned that on the foretibia there is a 'median spine-like process, sometimes also with an apical hook'. However, in that same year, the term 'epiphysis' was already associated with a structure located in the foretibia of butterflies and moths (Smith, 1895). Four years later, Sharp (1899, p. 314) described the epiphysis as a 'peculiar mobile pad' with peculiar scales, which could be used as comb organ.

In the early 20th century, Rothschild and Jordan (1903) used the term 'epiphysis' as a spur of the foretibia, indicating to be homologous to the spur of the middle tibia. Thereafter, the term 'epiphysis' appeared in glossaries as 'a movable process attached near the base of the inner side of the anterior tibia in many Lepidoptera' (Smith 1906, p. 140). But in others glossaries, the term 'Calcaria' appeared to refer to the tibial spurs (Jardine, 1913). Other terms are also found in the literature as 'strigils or strigilis' 
(Philpott, 1924; Costa Lima, 1945; Chapman, 1998) or 'fibula' (Zombori and Steinmann, 1999).

Of all the terms proposed in the literature to name the cleaning structure present in Lepidoptera ('Calcaria', 'Epiphysis', 'Strigil', 'Fibula'), the most used is 'epiphysis'; which I will use throughout the current research, due to the others terms are obsolete and 'strigilis' is used for the cleaning structure in ants.

The epiphysis is an synapomorphy of lepidopterans (Common, 1975; Kristensen, 2003; Kristensen et al., 2007), but it may be reduced or absent in some families (e.g. Acanthopteroctetidae, Lophocoronidae, Palaeosetidae, Anomosetidae, Cyclotornidae, Megalopygidae, Dalceridae, Pieridae, Nymphalidae and Lycaenidae). Whether present or reduced, it is located on inner surface of the foretibia (Philpott, 1924; Callahan and Carlysle, 1971; Odell et al., 1982; Robbins, 1989; Kristensen, 1999, 2003; Kristensen et al., 2007).

Epiphyses are multicellular outgrowths, which may be derived from the unpaired spur present in the same location in the Amphiesmenoptera ground plan (Whalley, 1986; Kristensen, 2003; Kristensen et al., 2007). This specialized spur is a movable process (Rothschild and Jordan, 1903; Richards and Richards, 1979; Odell et al., 1982; Kristensen, 2003; Triplehorn and Johnson, 2005) and it is covered by a cuticular protuberances called acanthae (Richards and Richards, 1979; Odell et al., 1982; Gorb, 2001).

Acanthae are projections of unicellular composition that have as morphological characteristic the lack a socket and a sensory cell (Richards and Richards, 1979; Gorb, 2001). Those projections are present in various structures of many insects and can to be various shapes (bifurcated, fimbriate, composed pectines or combs, with straight or bent tips) (Richards and Richards, 1979; Gorb, 2001). In Lepidoptera, they have a spatulated-shaped and have a mechanic function on the epiphysis (Odell et al., 1982).

Due to the presence of acanthae covering the structure, the function of the epiphyses as an antenna cleaning structure is not debatable. Several authors indicate that butterflies and moths clean themselves using the epiphyses, which is a very efficient 
mechanism for the grooming (Philpott, 1924; Costa Lima, 1945; Callahan and Carlysle, 1971; Odell et al., 1982; Robbins, 1989; Kristensen, 2003; Sambaraju et al., 2016). The antennae are cleaned with the legs of its corresponding side, for that, the antenna is put in the angle between the appendage and the foretibia, doing this repeatedly (Jander, 1966; Robbins, 1989; Kristensen, 2003; Sambaraju et al., 2016).

On the other hand, this cleaning structures vary in shape, size and origin. Such variation is widespread in several families, genera and species (Philpott, 1924) and some examples may be found in the following species: Helicoverpa zea (Boddie, 1850), Lymantria dispar (Linnaeus, 1758), Manduca sexta (Linnaeus, 1763), various species of Papilionidae (Papilio glaucus Linnaeus, 1758, Baronia brevicornis Salvin, 1893 and Parnassius clodius Ménétries, 1855) and Hesperiidae (Erynnis juvenalis (Fabricius, 1793), Poanes zabulon Boisduval \& LeConte (1837), Pyrrhopyge araxes Hewitson, 1867, Megathymus yuccae (Boisduval \& Leconte, [1837]), M. ursus Poling, 1902 and Carterocephalus palaemon (Pallas, 1771) (Callahan and Carlysle, 1971; Odell et al., 1982; Robbins, 1989; Kent and Griffin, 1990). Descriptions of the epiphyses in the works abovementioned were poorly detailed.

For all the above, the importance of the epiphysis is highlighted by its role as antennal cleaner and as informative character for taxonomists. First, the structure is important for butterflies and moths, which need to clean the antennae regularly for maintaining the fitness (details below in section 1.4). Second, these structures are useful for taxonomists. In the literature, there are several scientific articles considering the epiphysis as diagnostic character for the description of species (Philpott, 1924; Burrows, 1932; Lemaire and Wolfe, 1988; Schoorl, 1990; Minet, 1994; Schmitt et al., 1996; Mielke et al., 2008; Mielke and Drechsel, 2009; Pinheiro et al., 2011; Mielke and Casagrande, 2013; Castro-Torres and Llanderal-Cázares, 2016; Perini et al., 2019).

In our group of study, there is little information on the epiphyses. Hawkmoths have prominent and well-developed epiphyses (Philpott, 1924; Madden, 1944; Kristensen, 1999, 2003). These structures may vary in length, position (Rothschild and Jordan, 1903; Philpott, 1924), and they also may vary between sexes (Kent and Griffin, 
1990) with a comb on the margin of inner fold (Philpott, 1924; Madden, 1944). These characteristics are taxonomically informative in Sphingidae; nevertheless, in addition to the characters already mentioned (length and position), there may exist others features potentially important for taxonomic purposes.

\subsection{Antenna: Function, shape, importance and its relation with the epiphysis}

Antennae are appendages of the head; they are movable olfactory sensors found in all insects (Callahan, 1975; Snodgrass and Eickwort, 1993; Chapman, 1998). Due to the high presence and variety of sensilla, they are sensory structures (Snodgrass and Eickwort, 1993; Chapman, 1998; Field and Matheson, 1998), and function olfactory, gravitational, thermosensory and thermo-hygrosensory (Trouvelot, 1877; Chapman, 1998; Field and Matheson, 1998; Shields and Hildebrand, 1999a, 1999b; Böröczky et al., 2013).

These sensorial structures are quite variable in shape among insect groups; and sexual dimorphism is common (Chapman, 1998; Triplehorn and Johnson, 2005). Moths and butterflies have morphologically distinct antennae, and it is often possible to observe sexual dimorphism in these structures (Chapman, 1998; Symonds et al., 2011; Li et al., 2018). Having the hawkmoths as the object of our study, they have antennae often lamellate ventrally and roughly filiform, clavate, setiform or pectinate (bi-, tri- or quadripectinate) and apex usually hook-shaped (Schreiber, 1978; Kristensen, 1999). Furthermore, there may have differences between male and female (Madden, 1944; Schreiber, 1978; Kristensen, 1999). Males have two rows of long trichoid sensilla, while in females these sensilla are absent or shorter (Madden, 1944; Kristensen, 1999).

The association between the antennae and epiphyses is indisputable; because the only function of the epiphysis is to clean the sensory organ (Philpott, 1924; Jander, 1966; Callahan and Carlysle, 1971; Odell et al., 1982; Kent and Griffin, 1990). Philpott (1924) (p. 215) indicated: 'Species with the most plumose antennae have the most highly developed strigilis'. He concluded that the development of the epiphysis could to be 
associated with shape of the antennae. However, the variation of the epiphysis may also be correlated with other parameters not yet studied.

To summarize, there are still discrepancies in the taxonomy of Sphingidae, and to clarify or resolve some uncertainties of a taxonomic nature, more and better characters are needed. Epiphyses as a synapomorphy of moths and butterflies can be one of those key characters; however, the details of such characteristics have been little explored. On the other hand, as it is a potential antenna cleaning organ in Lepidoptera, it is presumed that its morphology is associated with the shape of the antennae and other parameters. For all the reasons, the main objectives of this study are:

- $\quad$ To present a detailed morphological study of the epiphyses of representatives of the tribes Dilophonotini and Philampelini.

- $\quad$ To describe the morphological variation among species of Dilophonotini and Philampelini.

- $\quad$ To quantify the size and shape variation of the epiphyses of Dilophonotini and Philampelini.

- $\quad$ To clarify the correlation between the epiphysis (epiphysis length, epiphysis width, position of the epiphysis) and others parameters (antenna length and foretibia length). 


\section{CONCLUSIONS}

For the first time, the morphology of the epiphyses of 59 species of Dilophonotini and Philampelini were examined and described in detail using different tools such as steromicrocospe, SEM, and geometric morphometrics. Furthermore, statistical analyzes were carried out to show relationships with other body measurements including antenna length, tibia length and epiphysis position. New terminologies were proposed to standardize future studies aiming a better understanding of the structure.

All the species examined showed typical epiphyses with comb on the inner margin, which appears to be a common feature of several lepidopteran groups, and it is presumed to be a character that independently evolved in various lineages or/and that has been lost several times. Additionally, 22 characters are established to assist in the description and comparison of the epiphyses among species, genera and tribes. Nevertheless, variation of these characters is more evident in genera and tribe levels.

A significant positive allometry demonstrated a relationship between the position of the epiphyses and the foretibia length; in the same way, between the antennae length and the epiphysis length. Epiphyses are sexually dimorphic structures in various characters, including those related to size. Most males have longer epiphyses than females, which may be associated with the antennae length rather than body-size, the variation between males and females are showed in the antennae length.

Geometric morphometrics showed that some species are more similar to other genera than those that are currently classified. Evolutionary allometry is not an important factor in the evolution of our group of study, and some closely related genera do not have similar epiphyses shape, which might indicate rapid radiation events or strong selective pressures on this structure.

This study is an initial contribution to a more comprehensive understanding of the evolution of the lepidopteran epiphyses, with detailed and illustrated descriptions. We claim for other studies that can reveal new morphological patterns in other moths and butterflies. 


\section{REFERENCES}

Acker, T. S. 1966. Courtship and Mating Behavior in Agulla Species (Neuroptera: Raphidiidae). Annals of the Entomological Society of America, 59(1): 1-6. doi: 10.1093/besa/3.2.4a.

Arnqvist, G. \& Mårtensson, T. 1998. Measurement error in geometric morphometrics: Empirical strategies to assess and reduce its impact on measures of shape, Acta Zoologica Academiae Scientiarum Hungaricae, 44(1-2):73-96.

Barão, K. R.; Ferrari, A. \& Grazia, J. 2013. Arthropod Structure \& Development Comparative morphology of selected characters of the Pentatomidae foreleg (Hemiptera, Heteroptera). Arthropod Structure and Development, 42(5): 425-435. doi: 10.1016/j.asd.2013.04.004.

Barber, G. W. \& Starnes, E. B. 1949. The activities of house flies. Journal of the New York Entomological Society, 57(4): 203-214.

Basibuyuk, H. H. \& Quicke, D. L. J. 1999. Grooming behaviours in the Hymenoptera (Insecta): Potential phylogenetic significance. Zoological Journal of the Linnean Society, 125(3): 349-382. doi: 10.1111/j.1096-3642.1999.tb00597.x.

Benítez, H. A.; Parra, L. E.; Sepulveda, E. \& Sanzana, M. J. 2011. Geometric perspectives of sexual dimorphism in the wing shape of Lepidoptera: The case of Synneuria sp. (Lepidoptera: Geometridae). Journal of the Entomological Research Society, 13(1): 53-60.

Benítez, H. A. \& Püschel, T. A. 2014. Modelando la varianza de la forma: Morfometría geométrica aplicaciones en biología evolutiva. International Journal of Morphology, 32(3): 998-1008. doi: 10.4067/S0717-95022014000300041.

Benítez, H. A. \& Vargas, H. A. 2017. Sexual dimorphism and population differentiation in the Chilean Neotropical moth Macaria mirthae (Lepidoptera, Geometridae): a wing geometric morphometric example. Revista Brasileira de Entomologia, 61(4): 365-369. doi: 10.1016/j.rbe.2017.06.003.

Böröczky, K.; Wada-Katsumata, A.; Batchelor, D.; Zhukovskaya, M. \& Schal, C. 2013. Insects groom their antennae to enhance olfactory acuity. Proceedings of the National Academy of Sciences, 110(9): 3615-3620. Available at: http://www.pnas.org/lookup/doi/10.1073/pnas.1212466110.

Brugnera, R.; Barão, K. R.; Roell, T. \& Ferrari, A. 2018. Comparative morphology of selected foretibial traits of Asopinae (Hemiptera: Heteroptera: Pentatomidae. Zoologischer Anzeiger, 2018: 1-19. doi: 10.1016/j.jcz.2018.10.011.

Burmeister, H. \& Shuckard, W. E. 1836. A Manual of Entomology. London, E. Churchton. doi: https://doi.org/10.5962/bhl.title.2063.

Burrows, C. R. 1932. Notes on the Psychidae XIII (with plate). The entomologist's record and Journal of variation, 44 (10): 133. 
Cai, X.; Su, X.; Huang, D. \& Shen, Z. 2019. Digital Classification of Sphingid Moths adults (Lepidoptera: Sphingidae) Based on Geometric Morphometry. Scientia Silvae Sinicae, 55(1) doi: 10.11707/j.1001-7488.20190105.

Callahan, P. S. 1975. Insect antennae with special reference to the mechanism of scent detection and the evolution of the sensilla', International Journal of Insect Morphology and Embryology, 4(5): 381-430. doi: 10.1016/0020-7322(75)90038-0.

Callahan, P. S. \& Carlysle, T. C. (1971). A function of the Epiphysis on the Foreleg of the Corn Earworm Moth, Heliothis zea. Annals of the Entomological Society of America, 64(1): 309-311.

Camargo, W. R. F.; Camargo, N. F.; Carmo Vieira Corrêa, D.; Camargo, A. J. A.; Diniz, I. R. \& Martin, O. 2015. Sexual dimorphism and allometric effects associated with the wing shape of seven moth species of Sphingidae (Lepidoptera: Bombycoidea). Journal of Insect Science, 15(1): 1-9. doi: 10.1093/jisesa/iev083.

Castro-Torres, R. \& Llanderal-Cázares, C. 2016. Detailed morphology of all life sof the agave red worm, Comadia redtenbacheri (Hammerschmidt) (Lepidoptera: Cossidae). Neotropical Entomology, 45(6): 698-711. doi: 10.1007/s13744-016-0425-7.

Chapman, R. F. 1998. The insects: Structure and function. 4. Ed. Cambridge University Press.

Chouvenc, T.; Su, N. Y. \& Robert, A. 2009. Cellular encapsulation in the eastern subterranean termite, Reticulitermes flavipes (Isoptera), against infection by the entomopathogenic fungus Metarhizium anisopliae. Journal of Invertebrate Pathology, 101(3): 234-241. doi: 10.1016/j.jip.2009.05.008.

Common, I. F. B. 1975. Evolution and classification of the Lepidoptera. Annual Review of Entomology, 20: 183-203.

Cook, J. L. 2014. Review of the biology of parasitic insects in the order strepsiptera. Comparative Parasitology, 81(2): 134-151. doi: 10.1654/4723.1.

Corbet, S. A. 1973. Concentration effects and the response of Nemeritis canescens to a secretion of its host. Journal of Insect Physiology, 19(11): 2119-2128.

Costa Lima, Â. M. 1945. Insetos do Brasil - Lepidópteros. In: Insetos do Brasil. Rio de Janeiro, Escola Nacional de Agronomia. v. 5, 420 p.

Dong, H. \& Huang, M. 2013. Analysis of the anointing and grooming behavior of several adult insects in Typhlocybinae (Hemiptera: Cicadellidae). Journal of Insect Behavior, 26(4): 540-549. doi: 10.1007/s10905-012-9370-4.

Dryden, I. L. \& Mardia, K. V. 2016. Statistical shape analysis with applications in R. 2.ed. Computer Vision. Wiley.

Duarte, M.; Carlin, L. F. \& Marconato, G. 2008. Light-attracted hawkmoths (Lepidoptera: Sphingidae) of Boracéia, municipality of Salesópolis, state of São Paulo, Brazil. Check List, 4(2): 123-136. 
Ellington, C. P. 1980. Wing mechanics and take-off preparation of Thrips (Thysanoptera). Journal of Experimental Biology, 85: 129-136.

Fabricius, J. C. 1807. Systema glossatorum secundum ordines, genera, species, adiectis, synonymis, locis, observationibus, descriptionibus. Brunovici, C. Reichard. doi: https://doi.org/10.5962/bhl.title.137098.

Farish, D. J. 1972. The evolutionary implications of qualitative variation in the grooming behaviour of the hymenoptera (Insecta). Animal Behaviour, 20(4): 662-676. doi: 10.1016/\$00033472(72)80139-8.

Field, L. H. \& Matheson, T. 1998. Chordotonal organs of insects. Advances in Insect Physiology, 27: 230.

Fox, J. \& Weisberg, S. 2019. An R companion to applied regression. 3.ed. Sage, Thousand Oaks CA.

Gorb, S. N. 2001. Attachment devices of insect cuticle. Dordrecht, Kluwer Academic Publishers.

Grassé, P.-P. 1986. Termitologia, comportament, socialite, ecologie, evolution. systématique. In: Traité de zoologie. Paris, Masson.

Grimaldi, D. \& Engel, M. S. 2005. Evolution of the Insects. Cambridge University Press.

Hackmann, A.; Delacave, H.; Robinson, A.; Labonte, D. \& Federle, W. 2015. Functional morphology and efficiency of the antenna cleaner in Camponotus rufifemur ants. Royal Society Open Science, 2(7): 1-10. doi: 10.1098/rsos.150129.

Hammer, Ø.; Harper, D. A. T. \& Ryan, P. D. 2001. PAST: Paleontological Statistics Software Package for Education and Data Analysis. Palaeontologia Electronica, p. 4-9. http://palaeoelectronica.org/2001 1/past/issue1 01.htm

Haxaire, J. \& Mielke, C.G. 2020. A revised and annotated checklist of the Brazilian Sphingidae with new records, taxonomical notes, and description of one new species (Lepidoptera Sphingidae). The European Entomologist, 11(3+4): 101-187.

Hlavac, T. F. 1971. Differentiation of the carabid antenna cleaner. Psyche, 78(1-2): 51-65.

Hlavac, T. F. 1975. Grooming systems of insects: structure, mechanics. Annals of the Entomological Society of America, 68(5): 823-826. doi: 10.1093/aesa/68.5.823.

Hosoda, N. \& Gorb, S. N. 2011. Friction force reduction triggers feet grooming behaviour in beetles. Proceedings of the Royal Society B: Biological Sciences, 278: 1748-1752. doi: 10.1098/rspb.2010.1772.

Hyndman, R.J. \& Khandakar, Y. 2008). Automatic time series forecasting: the forecast package for R. Journal of Statistical Software, 26(3): 1-22.

Rohlf, J. \& Slice, D. 1990. Extensions of the Procrustes method for the optimal superimposition of landmarks. Systematic Zoology, 39(1): 40-59. 
Jander, R. \& Jander, U. 2011. Wing grooming in bees (Apoidea) and the evolution of wing grooming in Insects. Journal of the Kansas Entomological Society, 51(4): 653-665.

Jander, U. 1966. Untersuchungen zur Stammesgeschichte von Putzbewegungen von Tracheaten. Zeitschrift für Tierpsychologie, 23(7): 799-844.

Jardine, N. K. 1913. The dictionary of Entomology. Ashford, Headley Bros.

Jones, G. D. \& Jones, S. D. 2001.The uses of pollen and its implication for entomology. Neotropical Entomology, 30(3): 341-350. doi: 10.1590/S1519-566X2001000300001.

Kathirithamby, J. 1989. Review of the order Strepsiptera. Systematic Entomology, 14(1): 41-92. doi: 10.1111/j.1365-3113.1989.tb00265.x.

Kawahara, A. Y.; Mignault, A. A.; Regier, J. C.; Kitching, I. J. \& Mitter, C. 2009. Phylogeny and biogeography of hawkmoths (Lepidoptera: Sphingidae): Evidence from five nuclear genes. PLoS ONE, 4(5) : 1-11. doi: 10.1371/journal.pone.0005719.

Kawahara, A. Y.; Plotkin, D.; Hamilton, C. A.; Gough, H.; St Laurent, R.; Owens, H. L.; Homziak, N. T. \& Barber, J. R. 2018. Diel behavior in moths and butterflies: a synthesis of data illuminates the evolution of temporal activity. Organisms Diversity and Evolution, 18(1): 13-27. doi: 10.1007/s13127-017-0350-6.

Kawahara, A. Y. \& Barber, J. R. 2015. Tempo and mode of antibat ultrasound production and sonar jamming in the diverse hawkmoth radiation. Proceedings of the National Academy of Sciences of the United States of America, 112(20):6407-6412. doi: 10.1073/pnas.1416679112.

Kent, K. S. \& Griffin, L. M. 1990. Sensory organs of the thoracic legs of the moth Manduca sexta', Cell and Tissue Research, 259(2): 209-223. doi: 10.1007/BF00318442.

Kirby, W. \& Spence, W. 1826. An introduction to Entomology on elements of the Natural History of Insects: with plates. 4.ed. London, Longman, Hurst, Rees, Orme, and Brown. doi: https://doi.org/10.5962/bhl.title.65745.

Kitching, I. J.; Rougerie, R.; Zwick, A.; Hamilton, C. A.; ST Laurent, R. A.; Naumann, S.; Mejia, L B. Kawahara, A. Y. 2018. A global checklist of the Bombycoidea (Insecta: Lepidoptera). Biodiversity Data Journal, 6(e22236). doi: 10.3897/BDJ.6.e22236.

Kitching, I. J. \& Cadiou, J.-M. 2000. Hawkmoths of the World: an annotated and illustrated revisionary checklist (Lepidoptera: Sphingidae). Ithaca, Cornell University Press.

Klingenberg, C. P. 2011. MorphoJ: An integrated software package for geometric morphometrics. Molecular Ecology Resources, 11(2): 353-357. doi: 10.1111/j.1755-0998.2010.02924.x.

Klingenberg, C. P. 2013a. Cranial integration and modularity: Insights into evolution and development from morphometric data. Hystrix, 24(1): 43-58. doi: 10.4404/hystrix-24.1-6367.

Klingenberg, C. P. 2013b. Visualizations in geometric morphometrics: How to read and how to make graphs showing shape changes. Hystrix, 24(1): 15-24. doi: 10.4404/hystrix-24.1-7691. 
Klingenberg, C. P. 2016. Size, shape, and form: concepts of allometry in geometric morphometrics. Development Genes and Evolution, 226(3): 113-137. doi: 10.1007/s00427-016-0539-2.

Klingenberg, C. P. \& Gidaszewski, N. A. 2010. Testing and quantifying phylogenetic signals and homoplasy in morphometric data. Systematic Biology, 59(3): 245-261. doi: 10.1093/sysbio/syp106.

Klingenberg, C. P. \& Marugán-Lobón, J. 2013. Evolutionary covariation in geometric morphometric data: Analyzing integration, modularity, and allometry in a phylogenetic context. Systematic Biology, 62(4): 591-610. doi: 10.1093/sysbio/syt025.

Kostromytska, O.; Scharf, M. E. \& Buss, E. A. 2015. Types and functions of mole cricket (Orthoptera: Gryllotalpidae) antennal and palpal sensilla. Florida Entomologist, 98(2): 593-605. doi: 10.1653/024.098.0232.

Kovac, D. \& Maschwitz, U. 1990. Secretion-grooming in aquatic beetles (Hydradephaga): a chemical protection against contamination of the hydrofuge respiratory region. Chemoecology, 1(3-4): 131-138. doi: 10.1007/BF01241654.

Kovac, D. \& Maschwitz, U. 1991. The function of the metathoracic scent gland in corixid bugs (Hemiptera, corixidae): secretion-grooming on the water surface. Journal of Natural History, 25(2): 331-340. doi: 10.1080/00222939100770241.

Kristensen, N. P. 1999. Lepidoptera, moths and butterflies Volume 1: Evolution, Systematics, and Biogeography. In: Handbook of zoology. , Volume IV, Arthropoda: Insecta. Fisher Maximilian. Part 35.

Kristensen, N. P. 2003. Lepidoptera, Moths and Butterflies Volume 2: Morphology, Physiology, and Development. In: Handbook of Zoology, Volume IV, Arthropoda: Insecta. Fisher Maximilian. Part 36.

Kristensen, N. P.; Scoble, M. J. \& Karsholt, O. 2007. Lepidoptera phylogeny and systematics: the state of inventorying moth and butterfly diversity. Zootaxa, 1668: 699-747.

Lefebvre, L. 1981. Grooming in crickets: Timing and hierarchical organization. Animal Behaviour, 29(4): 973-984. doi: 10.1016/S0003-3472(81)80050-4.

Leite, L. A. R.; Casagrande, M. M. \& Mielke, O. H. H. 2010. External morphology of the adult of Heraclides anchisiades capys (Hũbner, [1809]) (Lepidoptera-Papilionidae) III. Abdomen. Brazilian Archives of Biology and Technology, 53(6): 1407-1416. doi: 10.1590/S151689132011000200015.

Lemaire, C. \& Wolfe, K. L. 1988. Three new species of Paradirphia (Saturniidae: Hemileucinae) from Mexico and Central America with notes on the immature stages. The Journal of Research on the Lepidoptera, 27(3-4): 197-212.

Léonard, N. J.; Forbes, M. R. \& Baker, R. L. 1999. Effects of a mite, Limnochares americana (Hydrachnida: Limnocharidae), on the life-history traits and grooming behaviour of its damselfly 
host, Enallagma ebrium (Odonata: Coenagrionidae). Canadian Journal of Zoology, 77(10): 1615-1622. doi: 10.1139/cjz-77-10-1615.

Leung, B.; Forbes, M. R. \& Baker, R. L. 2001. Nutritional stress and behavioural immunity of damselflies. Animal Behaviour, 61: 1093-1099. doi: 10.1006/anbe.2001.1693.

Li, Y.; Liu, F.; Du, X.; Li, Z. \& Wu, J. 2018. Ultrastructure of antennal sensilla of three fruit borers (Lepidoptera: Crambidae or Tortricidae). PLoS ONE, 13(10): 1-10.

Linley, J. R. and Cheng, L. 1974. The grooming organs of Culicoides (Diptera: Ceratopogonidae). Mosquito News, 34(2): 204-206.

Lusebrink, I.; Dettner, K. \& Seifert, K. 2008. Stenusine, an antimicrobial agent in the rove beetle genus Stenus (Coleoptera, Staphylinidae). Naturwissenschaften, 95: 751-755. doi: 10.1007/s00114-008-0374-z.

Madden, A. H. 1944. The external morphology of the adult tobacco hornworm (Lepidoptera, Sphingidae). Annals of the Entomological Society of America, 37(2): 145-160.

Messenger, C. 1997. The Sphinx Moths (Lepidoptera: Sphingidae) of Nebraska. Transactions of the Nebraska Academy of Sciences, 24:89-141.

Meyrick, E. 1895. A handbook of British Lepidoptera. New York, Macmillan.

Mielke, C. G. C. \& Almeida-Neto, G. P. 2007. Description of a new species of Automeris Hübner, [1819] from Northeastern Brazil and notes about Automeris castrensis Schaus, 1898 from Southern Brazil (Lepidoptera: Saturniidae, Hemileucinae, Hemileucini). Nachrichten des Entomologischen Vereins Apollo, 28(1/2): 89-92.

Mielke, C. G. C.; Brosch, U. \& Naumann, S. 2008. Notes on the Neotropical genus Dirphiopsis Bouvier, 1928 with description of a new species (Lepidoptera: Saturniidae, Hemileucinae, Hemileucini. Nachrichten des Entomologischen Vereins Apollo, 28(3/4): 125-130.

Mielke, C. G. C. \& Casagrande, M. M. 2013. A new Cibyra Walker, 1856 from southern Brazil with taxonomic notes (first note) (Lepidoptera, Hepialidae. Nachrichten des Entomologischen Vereins Apollo, 34(1/2): 73-86.

Mielke, C. G. C. \& Drechsel, U. 2009. Description of a new Eudyaria Grote, 1896 from Paraguay (Lepidoptera: Saturniidae, Hemileucinae, Hemileucini). Nachrichten des Entomologischen Vereins Apollo, 30(1/2): 93-94.

Miller, W. E. 1997. Diversity and evolution of tongue length in hawkmoths (Sphingidae). Journal of the Lepidopterists' Society, 51(1): 9-31.

Minet, J. 1994. The Bombycoidea: phylogeny and higher classification (Lepidoptera, Glossata). Entomologica Scandinavica, 25(1): 63-88.

Misof, B.; Liu, S.; Meusemann, K.; Peters, R. S.; Donath, A.; Mayer, C.; Frandsen, P. B.; Ware, J.; Flouri, T.; Beutel, R. G.; Niehuis, O.; Petersen, M.; Izquierdo-Carrasco, F.; Wa:ler, T.; Rust, J.; 
Aberer, A. J.; Aspöck, U. Aspöck, H.; Bartel, D.; ... \& Zhou, X. 2014. Phylogenomics resolves the timing and pattern of insect evolution. Science, 346(6210): 763-767. doi: 10.1126/science.1257570.

Mitter, C.; Davis, D. R. \& Cummings, M. P. 2017. Phylogeny and evolution of Lepidoptera. Annual Review of Entomology, 62(1): 265-283. doi: 10.1146/annurev-ento-031616-035125.

Monteiro, L. R. 1999. Multivariate Regression models and geometric morphometrics: the search for causal factors in the analysis of shape. Systematic Biology, 48(1): 192-199.

Moré, M.; Kitching, I. J. \& Cocucci, A. A. 2014. Lepidoptera: Sphingidae. In: Roig-Juñent, S.; Claps, L. E. \& Morrone, J. J. (Eds). Biodiversidad de Artrópodos Argentinos. Mendoza, Sociedad Entomologica Argentina. p. 281-296.

Moritz, G. 1999. The biology of thrips is not the biology of their adults : a developmental view. In: Thrips and Tospoviruses. International Symposium on Thysanoptera, 7ㅇ. Proceedings. Camberra, Australian National Insect Collection, 2002. p. 259-267.

Mound, L. A. \& Walker, A. K. 1982. Terebrantia (Insecta: Thysanoptera). Fauna of New Zeland, 1:1113. doi: 10.7931/J2/FNZ.1.

Murray, M. D. 1987. Effects of host grooming on louse populations. Parasitology Today, 3(9): 276278. doi: 10.1016/0169-4758(87)90105-0.

Ndomo-Moualeu, A. F.; Ulrichs, C.; Radek, R. \& Adler, C. 2014. Structure and distribution of antennal sensilla in the Indianmeal moth, Plodia interpunctella (Hübner, 1813) (Lepidoptera: Pyralidae). Journal of Stored Products Research, 59: 66-75. https://doi.org/10.1016/j.jspr.2014.05.003.

van Nieukerken, E. J.; Kaila, L.; Kitching, I. J.; Kristensen, N. P.; Lees, D. C.; Minet, J.; Mitter, C.; Mutanen, M.; Regier, J. C.; Simonsen, T. J.; Wahlberg, N.; Yen, S.-H.; Zahiri, R.; Adamski, D. \& Baixera, A. 2011. Order Lepidoptera Linnaeus, 1758. In: Zhang, Z.-Q. (Ed.) Animal biodiversity: an outline of higher-level classification and survey of taxonomic richness. Auckland, Magnolia Press. p. 212-221.

Odell, T. M.; Shields, K. S.; Mastro, V. C. \& Kring, T. J. 1982. The epiphysis of the gypsy moth, Lymantria dispar (Lepidoptera: Lymantriidae): Structure and function. The Canadian Entomologist, 114(8): 751-761.

Perini, C. R.; Angulo, A. O.; Olivares, T. S.; Arnemann, J. A. \& Carus Guedes, J. V. 2019. New morphological key using male prothoracic leg characters to identify Helicoverpa (Lepidoptera: Noctuidae) species. Australian Journal of Crop Science, 13(9): 1561-1565. doi: 10.21475/ajcs.19.13.09.p2031.

Pettis, J. S. \& Pankiw, T. 1998. Grooming behavior by Apis mellifera L. in the presence of Acarapis woodi (Rennie) (Acari: Tarsonemidae. Apidologie, 29(3): 241-253. doi: 10.1051/apido:19980304. 
Philpott, A. 1924. The tibial Strigil of the Lepidoptera. Transactions and Proceedings of the Royal Society of New Zealand, 55: 215-224. Available at: http://rsnz.natlib.govt.nz/volume/rsnz_55/rsnz_55_00_002140.html.

Pinheiro, L. R.; Silva, R. O. \& Duarte, M. 2011. Immature stages of the moth Lobeza dentilinea (Lepidoptera: Notodontidae), with redescription of the species based on male and female morphology. Zoologia, 28(4): 517-524. doi: 10.1590/S1984-46702011000400014.

Rasband, W.S. 1997-2018. ImageJ. U. S. National Institutes of Health, Bethesda, Maryland, USA, https://imagej.nih.gov/ij/, 1997-2018.

Rebora, M.; Salerno, G.; Piersanti, S.; Michels, J. \& Gorb, S. N. 2019. Structure and biomechanics of the antennal grooming mechanism in the southern green stink bug Nezara viridula. Journal of Insect Physiology, 112(October): 57-67, 2018. doi: 10.1016/j.jinsphys.2018.12.002.

Regier, J. C.; Mitter, C.; Friedlander, T. P. \& Peigler, R. S. 2001. Phylogenetic relationships in Sphingidae (Insecta: Lepidoptera): initial evidence from two nuclear genes. Molecular Phylogenetics and Evolution, 20(2): 311-325. doi: 10.1006/mpev.2001.0963.

Richards, A. G. \& Richards, P. A. 1979. The cuticular protuberances of insects. International Journal of Insect Morphology and Embryology, 8: 143-157. doi: 10.1016/0020-7322(79)90013-8.

Robbins, R. K. 1989. Systematic implications of butterfly leg structures that clean the antennae. Psyche, 96(3-4): 209-222. doi: 10.1155/1989/43420.

Robinson, W. H. 1996. Antennal grooming and movement behaviour in the german cockroach, Blattella germanica (L.). In: International Conference on Urban Pests, 20. Proceedings. p. 361369.

Rohlf, F.J. 2017. tpsDig2. Version 2.31 [computer software]. Department of Ecology and Evolution, State University of New York, Stony Brook (https://life.bio.sunysb.edu/morph/)

Rohlf, F.J. 2019. tpsUtil32. Version 1.78 [computer software]. Department of Ecology and Evolution, State University of New York, Stony Brook (https://life.bio.sunysb.edu/morph/)

Rossa, R.; Goczał, J. \& Tofilski, A. 2016. Within- and between-species variation of wing venation in genus Monochamus (Coleoptera: Cerambycidae). Journal of Insect Science, 16 (1):1-5. 1-7. doi: 10.1093/jisesa/iev153.

Rothschild, W. \& Jordan, K. 1903. A revision of the Lepidopterous family Sphingidae. Novitates Zoologicae, 9:1-972.

R Core Team. 2018. R: A language and environment for statistical computing. (Version 3.5.2). [Computer Software]. Vienna, R Foundation for Statistical Computing.

RStudio Team. 2020. RStudio: Integrated Development for R. RStudio. Boston, PBC. http://www.rstudio.com/ 
Sambaraju, K. R.; Donelson, S. L.; Bozic, J. \& Phillips, T. W. 2016. Oviposition by female Plodia interpunctella (Lepidoptera: Pyralidae): description and time budget analysis of behaviors in laboratory studies. Insects, 7(1):1-16. doi: 10.3390/insects7010004.

Schluter, D. 1996. Ecological causes of adaptive radiation. The American Naturalist, 148(Suppl. S): S40-S64.

Schmitt, J. J.; Brown, M. W. \& Davis, D. R. 1996. Taxonomy, morphology and biology of Lyonetia prunifoliella (Lepidoptera: Lyonetiidae), a leafminer of apple. Annals of the Entomological Society of America, 89(3): 334-345.

Schönitzer, K. \& Lawitzky, G. 1987. A phylogenetic study of the antenna cleaner in Formicidae, Mutillidae, and Tiphiidae (Insecta, Hymenoptera). Zoomorphology, 107(5): 273-285. doi: 10.1007/BF00312173.

Schönitzer, K. \& Renner, M. 1984 .The function of the antenna cleaner of the Honeybee (Apis mellifica. Apidologie, 15(1): 23-32. doi: 10.1051/apido:19840103.

Schoorl, J. W. jr. 1990. A phylogenetic study on Cossidae (Lepidoptera: Ditrysia) based on external adult morphology. Zoologische Verhandelingen, 263: 1-295. doi: http://www.repository.naturalis.nl/record/317816.

Schreiber, H. 1978. Dispersal Centres of Sphingidae (Lepidoptera) in the Neotropical Region. Biogeographica, 10: 1-195. doi: 10.1007/978-94-009-9960-2.

Setty, L. R. 1940. Biology and morphology of some North American Bittacidae (Order Mecoptera). The American Midland Naturalist, 23(2): 257-353.

Sharp, D. 1899. Insects. Part II Hymenoptera continued (Tubulifera and Aculeata), Coleoptera, Strepsiptera, Lepidoptera, Diptera, Aphaniptera, Thysanoptera, Hemiptera, Anoplura. New York, Macmillan. doi: https://doi.org/10.5962/bhl.title.8698.

Shields, V. D. C. \& Hildebrand, J. G. 1999a. Fine structure of antennal sensilla of the female sphinx moth, Manduca sexta (Lepidoptera: Sphingidae). I. Trichoid and basiconic sensilla. Canadian Journal of Zoology, 77(2): 290-301. doi: 10.1139/cjz-77-2-290.

Shields, V. D. C. \& Hildebrand, J. G. 1999b. Fine structure of antennal sensilla of the female sphinx moth, Manduca sexta (Lepidoptera: Sphingidae). II. Auriculate, coeloconic, and styliform complex sensilla. Canadian Journal of Zoology, 77(2): 302-313. doi: 10.1139/z99-003.

Smith, B. J. \& Valentine, B. D. 1985. Phylogenetic implications of grooming behavior in Cockroaches (Insecta: Blattaria). Psyche, Cambridge, 92(4): 369-385.

Smith, J. B. 1895. Contribution toward a monograph of the insects of the Lepidopterous family Noctuidae of Boreal North America - A revision of the deltoid moths. Bulletin of the United States National Museum, Washington, 48:1-120. doi: https://doi.org/10.5962/bhl.title.39662. 
Smith, J. B. 1906. Explanation of terms used in Entomology. Brooklyn, Brooklyn Entomological Society. doi: https://doi.org/10.5962/bhl.title.1732.

Snodgrass, R. E. \& Eickwort, G. C. 1993. Principles of Insect morphology. London, Cornell University Press.

Stillwell, R. C.; Blanckenhorn, W. U.; Teder, T.; Davidowitz, G. \& Charles, W. F. 2010. Sex differences in phenotypic plasticity affect variation in sexual size dimorphism in insects: from physiology to evolution. Annual Review of Entomology, 55: 227-245. doi: 10.1146/annurev-ento-112408085500

Stojanovic, N.; Florea, L.; Riemer, C.; Gumucio, D.; Slightom, J.; Goodman, M.; Miller, W. \& Hardison, R. 1999. Comparison of five methods for finding conserved sequences in multiple alignments of gene regulatory regions. Nucleic Acids Research, 27(19): 3899-3910. doi: 10.1093/nar/27.19.3899.

Sumana, A. \& Starks, P. T. 2004. Grooming patterns in the primitively eusocial wasp Polistes dominulus. Ethology, 110(10): 825-833. doi: 10.1111/j.1439-0310.2004.01024.x.

Symonds, M. R. E.; Johnson, T. L. \& Elgar, M. A. 2011. Pheromone production, male abundance, body size, and the evolution of elaborate antennae in moths. Ecology and Evolution, 2(1):227246). doi: 10.1002/ece3.81.

Thelen, E. \& Farish, D. J. 1977. An analysis of the grooming behavior of wild and mutant strains of Bracon hebetor (Braconidae: Hymenoptera). Behaviour, 62(1/2): 70-102. doi: 10.1017/CBO9781107415324.004.

Toro Ibacache, M. V.; Manriquez Soto, G. \& Suazo Galdames, I. 2010. Morfometría geométrica y el estudio de las formas biológicas: de la morfología descriptiva a la morfología cuantitativa. International Journal of Morphology, 28(4): 977-990.

Trautwein, M. D.; Wiegmann, B. M.; Beutel, R. G.; Kjer, K. M. \& Yeates, D. K. 2012. Advances in Insect Phylogeny at the Dawn of the Postgenomic Era. Annual Review of Entomology, 57: 449468. doi: 10.1146/annurev-ento-120710-100538.

Triplehorn, C. A. \& Johnson, N. F. 2005. Borror and Delong's introduction of study of insects. 7.ed. Thomson Brooks/Cole.

Trouvelot, L. 1877. The use of the antennae in Insects. The American Naturalist, 11(4): 193-196.

Valentine, B. D. 1973. Grooming behavior in Coleoptera. The Coleopterists Bulletin, 27(2): 63-73.

Valentine, B. D. 1986. Grooming behavior in Embioptera and Zoraptera (Insecta). Ohio Journal of Science, 86(4): 150-152.

Vincent, C. M. \& Bertram, S. M. 2010. Crickets groom to avoid lethal parasitoids. Animal Behaviour, 79(1): 51-56. doi: 10.1016/j.anbehav.2009.10.001. 
Walker, E. D. \& Archer, W. E. 1988. Sequential organization of grooming behaviors of the mosquito, Aedes triseriatus. Journal of Insect Behavior, 1(1): 97-109. doi: 10.1007/BF01052506.

Walker, F. 1869. Characters of undescribed Lepidoptera Heterocera. London, E.W. Janson. doi: https://doi.org/10.5962/bhl.title.21064.

Warton, D. I.; Duursma, R. A.; Falster, D. S. \& Taskinen, S. 2012. smatr 3 - an R package for estimation and inference about allometric lines. Methods in Ecology and Evolution, 3(2): 257-259.

Wendler, G. \& Vlatten, R. 1993. The influence of aggregation pheromone on walking behaviour of cockroach males (Blattella germanica L.). Journal of Insect Physiology, 39(12): 1041-1050. doi: 10.1016/0022-1910(93)90128-E.

Whalley, P. 1986. A review of the current fossil evidence of Lepidoptera in the Mesozoic. Biological Journal of the Linnean Society, 28(3): 253-271.

Wickham. H. 2016. ggplot2: Elegant Graphics for Data Analysis. New York, Springer-Verlag.

Yanagawa, A.; Guigue, A. M. A. \& Marion-Poll, F. 2014. Hygienic grooming is induced by contact chemicals in Drosophila melanogaster. Frontiers in Behavioral Neuroscience, 8(July): 1-9. doi: 10.3389/fnbeh.2014.00254.

Zhukovskaya, M.; Yanagawa, A. \& Forschler, B. 2013. Grooming behavior as a mechanism of insect disease defense. Insects, 4(4): 609-630. doi: 10.3390/insects4040609.

Zombori, L. \& Steinmann, H. 1999. Dictionary of Insect Morphology, In: Kükenthal, W. (Ed.) Handbook of Zoology, Band 4: Arthropoda: Insecta. Berlin, De Gruyter. Part 34. 